JURNAL KETAHANAN NASIONAL

P-ISSN: 0853-9340, e-ISSN: 2527-9688

Online sejak 28 Desember 2015 di: http://jurnal.ugm.ac.id/JKN

\title{
PERAN PEMUDA DALAM PENGEMBANGAN EDUWISATA ENERGI TERBARUKAN DAN IMPLIKASINYA TERHADAP KETAHANAN EKONOMI WILAYAH \\ (Studi di Desa Poncosari Kecamatan Srandakan Kabupaten Bantul Daerah Istimewa Yogyakarta)
}

\author{
Ilma Fatimah Yusuf \\ Forum CSR Kessos DIY \\ Ilmafatimah92@gmail.com \\ Edhi Martono \\ Fakultas Pertanian Universitas Gadjah Mada \\ edhi.martono@ugm.ac.id \\ Agus Prasetya \\ Fakultas Teknik Universitas Gadjah Mada \\ aguspras@ugm.ac.id
}

\begin{abstract}
This research studied the role of youngster in development of renewable energy edutourism and its implication towards the regional economy resilience (study in Poncosari Village, Srandakan Subdistrict, Bantul Regency, Yogyakarta). Mean while the purpose of this research was to analyzed the role of youngster in development of renewable energy edutourism, and also to analyzed the implication of the role of youngster in development of renewable energy edutourism towards the regional economy resilience.

This research used qualitative descriptive method. Data collection technique was conducted by five steps, i.e.: 1) Observation, 2) Interview, 3) Documentation, 4) Literature, 5) Internet. Whereas data validity was conducted by cross check data technique.

The result of research showed the role of youngster joined in Work Group of renewable energy edutourism had conducted promotion in some educational institution or wide society, either directly or through printed media and online. The development of renewable energy edutourism had significant impact towards the regional economy resilience, because it had increased economical income of surrounding people. It could be considere as manifestation of the familial economical resilience of which was as basic of the regional economy resilience.
\end{abstract}

Keyword: The Role of Youngster, Development of Edutourism, Renewable Energy, Regional Economy Resilience.

\begin{abstract}
ABSTRAK
Penelitian ini mengkaji peran pemuda dalam pengembangan eduwisata energi terbarukan dan implikasinya terhadap ketahanan ekonomi wilayah (Studi di Desa Poncosari, Kecamatan Srandakan, Kabupaten Bantul, Yogyakarta). Adapun tujuan penelitian ini untuk menganalisis peran pemuda dalam pengembangan eduwisata energi
\end{abstract}


terbarukan, serta untuk menganalisis implikasi peran pemuda dalam pengembangan eduwisata energi terbarukan terhadap ketahanan ekonomi wilayah.

Penelitian ini menggunakan metode deskriptif kualitatif. PTeknik pengumpulan data dilakukan dengan lima tahap, yaitu: 1) Observasi, 2) Wawancara, 3) Dokumentasi 4) Kepustakaan, 5) Internet. Adapun validitas data dengan menggunakan teknik cross check data.

Hasil penelitian menunjukkan bahwa peran pemuda yang tergabung dalam POKJA eduwisata energi terbarukan telah melakukan promosi di beberapa instansi pendidikan maupun masyarakat luas, baik secara langsung maupun melalui media cetak dan online. Implikasi peran pemuda dalam pengembangan eduwisata energi terbarukan dapat dilihat dari jumlah pengunjung yang berkunjung langsung berkoordinasi dengan pengelola PLTH dan BIOGAS lebih banyak jika dibandingkan dengan yang menggunakan jasa POKJA. Pengembangan eduwisata energi terbarukan mempunyai dampak yang signifikan terhadap ketahanan ekonomi wilayah, karena telah meningkatkan pendapatan ekonomi warga sekitar. Hal ini dapat dikatakan sebagai wujud dari ketahanan ekonomi keluarga yang merupakan dasar dari ketahanan ekonomi wilayah.

Kata Kunci: Peran Pemuda, Pengembangan Eduwisata, Energi Terbarukan, Ketahanan Ekonomi Wilayah.

\section{PENGANTAR}

Ketahanan nasional merupakan sebuah konsepsi pertahanan yang bersifat semesta, serta bertujuan untuk kelangsungan hidup bangsa dan negara Indonesia yang merdeka dan berdaulat dengan mendasarkan pada kekuatan diri sendiri (Departemen Pertahanan RI, 2008). Sistem ketahanan nasional pada dasarnya bersifat semesta bercirikan pada kerakyatan, artinya hal tersebut diorientasikan untuk kepentingan rakyat. Berdasarkan hal tersebut, maka sumber daya (SDA dan SDM) yang ada didayagunakan sebagai upaya kepentingan sekaligus pertahanan nasional. Maka konsepsi ketahanan nasional (Indonesia) mencakup seluruh kehidupan nasional dirinci menjadi delapan aspek kehidupan, atau sering disebut sebagai Astagatra, yang terdiri dari trigatra dan pancagatra (Lemhannas, 1997). Trigatra merupakan aspek-aspek yang memang sudah melekat pada suatu negara dan bersifat alamiah. Unsur trigatra meliputi aspek geografi, kekayaan alam dan kependudukan. Pancagatra merupakan aspek-aspek kehidupan nasional yang menyangkut tata kehidupan dan pergaulan hidup manusia dalam bermasyarakat dan bernegara yang diikat dengan aturanaturan atau norma tertentu. Berkaitan dengan hal tersebut, maka konsep pancagatra sering disebut sebagai aspek sosial, yang mencakup unsur ideologi, politik, sosial-budaya, ekonomi dan keamanan.

Setiap negara sudah semestinya mempunyai tugas dan tanggung jawab untuk menjaga dan melindungi kedua aspek tersebut, baik yang bersifat alamiah maupun yang bersifat sosial. Tugas dan tanggungjawab tersebut tidak hanya dibebankan pada aparatur atau perangkat kenegaraan semata, akan tetapi semua warga negara juga mempunyai tugas dan tanggungjawab secara bersama untuk mempertahankan kedua aspek tersebut. Hal ini dilakukan supaya kedaulatan negara, keutuhan wilayah NKRI, keadilan dan kesejahteraan rakyat serta keselamatan segenap bangsa dapat terjaga dan terjamin dari segala bentuk ancaman baik dari dalam negeri maupun dari luar negeri.

Salah satu gatra dalam mewujudkan ketahanan nasional adalah aspek ekonomi. Ekonomi sebagai salah satu gatra dalam konsepsi ketahanan nasional merupakan faktor 
Ilma Fatimah Yusuf, Edhi Martono, Agus Prasetya -- Peran Pemuda Dalam Pengembangan Eduwisata Energi Terbarukan Dan Implikasinya Terhadap Ketahanan Ekonomi Wilayah (Studi Di Desa Poncosari Kecamatan Srandakan Kabupaten Bantul Daerah Istimewa Yogyakarta)

penting bagi kemajuan dan kesejahteraan sebuah bangsa. Semakin tinggi laju pertumbuhan ekonomi suatu negara seringkali menjadi tolok ukur kesejahteraan rakyat dan kemajuan sebuah bangsa. Bahkan perekonomian suatu negara dapat mempengaruhi kondisi sosial dan politik. Artinya, konflik sosial dan stabilitas politik yang dapat mengancam disintegrasi bangsa seringkali dipengaruhi oleh faktor ekonomi. Begitupula dengan pembangunan, baik dari segi infrastruktur maupun suprastruktur juga membutuhkan prasyarat ekonomi. Maka dari itu, stabilitas dan laju pertumbuhan ekonomi perlu diwujudkan agar ketahanan nasional dapat terwujud.

Kaitannya dalam mewujudkan ketahanan nasional, khususnya dalam bidang ekonomi, seperti yang sudah diulas pada alinea di atas harus melibatkan semua elemen yang ada, salah satunya adalah pemuda. Di tengah-tengah iklim globalisasi yang bermuara pada pasar bebas, maka pemuda sebagai generasi penerus bangsa perlu di dorong untuk meningkatkan daya produktivitas ekonomi, sehingga mampu bersaing dalam kompetisi tersebut. Tanpa adanya produktivitas kemandirian ekonomi, maka pemuda hanya akan menjadi konsumen, bukan produsen. Jika masyarakat Indonesia, khususnya pemuda sebagai generasi penerus bangsa hanya sebagai konsumen, maka laju perekonomian suatu negara akan mengalami stagnasi, sehingga ketahanan ekonomi akan sulit untuk terwujud. Pasalnya, tingkat produktivitas kemandirian ekonomi akan berdampak pada laju pertumbuhan ekonomi suatu negara.

Selanjutnya, laju pertumbuhan ekonomi suatu negara akan ditopang oleh peningkatan perekonomian suatu daerah. Maka dari itu, ketahanan ekonomi suatu daerah merupakan basis dari ketahanan nasional dalam bidang ekonomi, sehingga produktivitas ekonomi daerah merupakan syarat utama. Kemudian implementasi dari produktivitas ekonomi tidak hanya bersifat top down (dari atas), namun juga bottom up (dari bawah). Artinya di satu sisi pemerintah juga harus memberikan stimulus respon kepada masyarakat, khususnya pemuda untuk semakin produktif, namun di sisi lain, pemuda juga harus mempunyai daya kreatif dalam pengembangan ekonomi.

Selanjutnya, produktivitas ekonomi juga harus mendasarkan pada realitas objektif, artinya pengembangan perekonomian harus sesuai dengan potensi yang ada. Produktivitas ekonomi tanpa dilandasi oleh kondisi objektif, akan mengalami kesulitan dalam pengembangannya, bahkan dapat berujung pada stagnasi perekonomian. Senada dengan hal tersebut, Desa Poncosari yang notabene terletak di daerah pantai selatan Yogyakarta, sangat potensial jika dikembangkan sebagai objek wisata. Terlebih di daerah Pantai Baru Pandansimo terdapat pengembangan teknologi energi terbarukan, yaitu PLTH dan BIOGAS. Keberadaan diversifikasi energi terbarukan tersebut juga telah dimanfaaatkan oleh Pemuda Desa Poncosari sebagai objek wisata pendidikan. Keberadaan Pantai Baru Pandansimo yang di dalamnya terdapat pengembangan teknologi energi terbarukan merupakan kondisi objektif bagi masyarakat setempat untuk mengembangkan tempat tersebut sebagai objek wisata. Keberadaan PLTH dan BIOGAS yang dijadikan sebagai objek wisata berbasis pendidikan dapat menjadi daya tarik wisatawan untuk mengadakan kunjungan wisata. Pasalnya, secara kuantitatif jumlah objek wisata pendidikan masih minim, terlebih eduwisata energi terbarukan di Yogyakarta hanya ada di Desa Poncosari. 
Pengembangan eduwisata energi terbarukan telah diinisiasi oleh PUSTEK UGM yang bekerjasama dengan Karang Taruna Desa Poncosari. Kerjasama tersebut terjalin sejak tahun 2011 hingga tahun 2013, dengan membentuk Kelompok Kerja (POKJA) Eduwisata Energi Terbarukan dengan mengakomodir Pemuda Desa Poncosari. Pemuda Desa Poncosari yang tergabung dalam POKJA merupakan motor penggerak dari pengembangan eduwisata energi terbarukan tersebut. Berbagai pembekalan atau pelatihan telah dilakukan oleh PUSTEK UGM, agar pemuda yang tergabung dalam POKJA dapat mengembangkan eduwisata energy terbarukan secara mandiri.

Adapun harapan dari pengembangan eduwisata energi terbarukan yang dikelola oleh POKJA adalah untuk meminimalisir angka pengangguran dengan mendorong produktivitas pemuda, sehingga pemuda menjadi mempunyai penghasilan. Pengembangan eduwisata energi terbarukan yang dikelola oleh pemuda mempunyai implikasi terhadap ketahanan ekonomi wilayah. Pasalnya dengan adanya pengembangan eduwisata energi terbarukan, selain pemuda menjadi memperoleh penghasilan juga telah menjadi daya tarik wisatawan untuk berkunjung. Hal ini dapat dilihat dari meningkatnya jumlah wisatawan yang berkunjung dari tahun ke tahun. Untuk itu, penelitian ini menganalisis peran pemuda dalam pengembangan eduwisata energi terbarukan dan implikasinya terhadap ketahanan ekonomi wilayah.

Terdapat enam teori dalam penelitian ini yang bertujuan untuk mengarahkan peneliti agar mudah untuk melakukan penelitian. Adapun teori yang dimaksud adalah sebagai berikut.

Pertama, teori tentang peran erat kaitannya dengan keterlibatan atau partisipasi seseorang dalam sebuah kegiatan, baik secara langsung maupun tidak langsung. Maksud dari peran secara langsung adalah ketika seseorang terlibat aktif dalam sebuah proses kegiatan. Peran tidak langsung adalah ketika seseorang tidak melibatkan dirinya secara langsung dalam sebuah proses kegiatan namun, namun mempunyai peranan dalam terselenggarannya kegiatan tersebut.

Kedua, tentang pemuda yang dapat dilihat dalam Undang-Undang Nomor 40 Tahun 2009 Tentang Kepemudaan Pasal 1 ayat 1 , bahwa yang disebut pemuda adalah warga negara Indonesia yang sedang dalam masa pertumbuhan dan perkembangan usia 16 (enam belas) sampai 30 (tiga puluh) tahun.

Ketiga, eduwisata atau sering disebut sebagai wisata yang bersifat edukatif merupakan suatu konsep yang menggabungkan unsur wisata dengan muatan pendidikan di dalamnya. Menurut Rodger wisata pendidikan dimaksudkan sebagai suatu program di mana peserta kegiatan wisata melakukan perjalanan wisata pada suatu tempat tertentu dalam suatu kelompok dengan tujuan utama mendapatkan pengalaman belajar secara langsung terkait dengan lokasi yang dikunjungi (Anonim, 2013).

Keempat, energi terbarukan merupakan energi atau sumber energi yang dapat diperbaharui secara terus menerus, seperti air, panas bumi, energi surya, biomassa, gelombang, arus laut dan angin.

Kelima, ketahanan nasional merupakan sebuah konsepsi pertahanan yang bersifat semesta, serta bertujuan untuk kelangsungan hidup bangsa dan negara Indonesia yang merdeka dan berdaulat dengan mendasarkan pada kekuatan diri sendiri (Departemen Pertahanan RI, 2008). 
Ilma Fatimah Yusuf, Edhi Martono, Agus Prasetya -- Peran Pemuda Dalam Pengembangan Eduwisata Energi Terbarukan Dan Implikasinya Terhadap Ketahanan Ekonomi Wilayah (Studi Di Desa Poncosari Kecamatan Srandakan Kabupaten Bantul Daerah Istimewa Yogyakarta)

Keenam, ketahanan ekonomi adalah suatu kondisi dinamika wilayah yang berisi keuletan dan ketangguhan yang mengandung kemampuan untuk mengembangkan kekuatan dalam menghadapi dan mengatasi segala tantangan, ancaman, hambatan serta gangguan yang datang dari luar maupun dari dalam, baik secara langsung maupun tidak langsung membahayakan kehidupan ekonomi wilayah (Kusumasari, 2014).

Penelitian ini menggunakan metode deskriptif kualitatif, dimana peneliti akan mendeskripsikan fenomena tentang topik penelitian yang sedang dikaji. Adapun penentuan informan dalam penelitian ini dilakukan berdasar pada kriteria tertentu yang dapat menunjang penelitian ini. Selanjutnya teknik pengumpulan data dilakukan dengan lima tahap, yaitu: (1) Observasi, (2) Wawancara, (3) Dokumentasi (4) Kepustakaan, (5) Internet (Burhan, 2003). Adapun validasi data dengan menggunakan teknik cross check data. Kemudian teknik analisis data dalam penelitian ini, yakni: (1) reduksi data, (2) kategori data, (3) penyajian data, dan (4) penarikan kesimpulan (Sugoyono, 2007).

Tujuan penelitian ini adalah untuk menjawab perumusan masalah yaitu untuk mengetahui konsep dan peran pemuda dalam mengembangkan kawasan Eduwisata Energi Terbarukan di Desa Poncosari, dan untuk mengidentifikasi peranan pemuda dalam pengembangan kawasan Eduwisata Energi Terbarukan Poncosari yang berimplikasi terhadap ketahanan ekonomi wilayah.

\section{PEMBAHASAN}

\section{Gambaran Umum Lokasi Penelitian}

Desa Poncosari terdiri dari 24 Padukuhan yang meliputi 120 Rukun Tetangga (RT).
Pada dasarnya Desa Poncosari merupakan penggabungan dari 5 kelurahan, yakni Saptokondo, Wonotingal, Trihudadi, Sambikerto dan Mojourip. Penggabungan dari Lima kelurahan terjadi sejak Tanggal 05 September 1946. Secara geografis Desa Poncosari terletak ke dalam wilayah Kecamatan Srandakan, Kabupaten Bantul, Daerah Istimewa Yogyakarta, dengan luas wilayah 1.130 Ha. Lokasi tersebut berada di bagian barat daya Kabupaten Bantul, kurang lebih 30 kilometer $(\mathrm{km})$ dari Kota Yogyakarta, dan terletak di pesisir pantai selatan (Pandansimo) Yogyakarta, yang berhadapan langsung dengan Samudera Indonesia. Sebelah barat berbatasan langsung dengan Sungai Progo Kabupaten Kulon Progo, sebelah selatan dengan Samudera Indonesia, sebelah timur berbatasan dengan Desa Gadingsari Kecamatan Sanden, dan sebelah utara berbatasan dengan Desa Trimurti.

Desa Poncosari mempunyai Tiga destinasi wisata pantai, yaitu Pandansimo, Pantai Kuwaru, dan Pantai Baru Pandansimo. Dari ketiga pantai tersebut, adalah Pantai Baru Pandansimo merupakan tempat wisata yang paling ramai pengunjung. Pasalnya Pantai Baru merupakan pantai yang paling bersih dan indah daripada kedua pantai yang ada tersebut. Bahkan di dalam kawasan Pantai Baru terdapat pengembangan teknologi energi terbarukan (PLTH dan BIOGAS) yang dijadikan sebagai objek wisata pendidikan. Pengembangan eduwisata energi terbarukan tersebut telah menjadi daya taril masyarakat luas untuk berkunjung ke lokasi wisata tersebut. Hal ini terbukti, bahwa setiap tahunnya jumlah wisatawan yang berkunjung semakin meningkat.

Pengembangan eduwisata energi terbarukan merupakan ide dari PUSTEK UGM yang bekerjasama dengan Karang 
Taruna Desa Poncosari untuk membentuk Kelompok Kerja (POKJA). Realiasasi dari ide tersebut adalah dengan diadakannya pelatihan kepada pemuda desa agar mempunyai daya produktivitas. Pemuda yang tergabung dalam POKJA merupakan motor penggerak pengembangan eduwisata energi terbarukan, yang di bentuk pada tahun 2011, yang merupakan awal kerjasama antara PUSTEK UGM dengan pemuda Desa Poncosari untuk mengembangkan PLTH dan BIOGAS sebagai objek wisata. Kerjasama tersebut tertuang dalam sebuah MoU selama 3 tahun, yaitu sampai tahun 2013. Artinya setelah tahun 2013, PUSTEK UGM sudah tidak lagi terlibat secara struktural dalam pengembangan eduwisata tersebut. Akan tetapi pengembangan eduwisata tersebut, harapannya adalah dikelola secara mandiri oleh pemuda yang tergabung dalam POKJA.

\section{Profil Kelompok Kerja Desa Poncosari}

Kelompok Kerja atau POKJA eduwisata merupakan wadah perkumpulan warga masyarakat sekitar. Kelompok kerja secara terminologi merupakan wadah yang dibentuk oleh sekelompok orang dengan tujuan untuk mengadakan kegiatan kerja secara bersama. Hal ini sesuai dengan tujuan dibentuknya POKJA eduwisata yaitu untuk mengakomodir warga masyarakat, khususnya pemuda ke dalam suatu kegiatan kerja secara bersama. Kronologis terbentuk POKJA eduwisata tidak lepas dari peran pemuda yang tergabung dalam karang taruna desa. Menurut Pemaparan Nukman selaku ketua POKJA, terbentuknya kelompok kerja berawal dari adanya kerja sama antara Karang Taruna Desa Poncosari dengan Pusat Studi Ekonomi Kerakyatan (PUSTEK) UGM pada Tahun 2011 (Nukman:
Ketua Kelompok Kerja/ POKJA, 19 Februari 2016).

Kerjasama tersebut ditujukan untuk pengembangan destinasi wisata Pantai Baru Pandansimo, yaitu keberadaan penganekaragaman teknologi Energi Terbarukan sebagai objek wisata edukatif. Eduwisata Energi Terbarukan tersebut nantinya dikembangkan oleh pemuda yang tergabung dalam Kelompok Kerja (POKJA) Desa Poncosari. Berkaitan dengan hal tersebut, maka PUSTEK UGM memberikan dukungan dengan cara mengadakan pelatihan kepada pemuda Desa Poncosari tentang pembangunan dan manajemen eduwisata energi terbarukan ke depannya. Pelatihan dan pembinaan tersebut diselenggarakan dan dibiayai oleh PUSTEK UGM.

Kelompok Kerja (POKJA) Eduwisata Energi Terbarukan telah dibentuk pada tanggal 25 Maret 2011 di Aula Kantor Desa Poncosari, dan dihadiri oleh sekitar 30-an pemuda, Kepala Desa dan beberapa Kepala Dusun. Nukman Rifa i ditunjuk sebagai ketua POKJA melalui musyawarah tersebut beserta dengan beberapa anggota pengurus kelompok kerja. Menurut Nukman selaku Ketua POKJA, awal pembentukan kelompok kerja ini terdapat sekitar 38 pemuda yang tergabung, dengan usia sekitar 25-32 tahun.

Pemuda yang tergabung dalam POKJA tersebut tidak hanya pengurus Karang Taruna Desa Poncosari, namun terdapat juga pengurus karang taruna tingkat dusun. Jumlah keseluruhan pemuda tersebut merupakan representasi dari 10 dusun dari jumlah keseluruhan dusun yang ada, yakni 24 dusun. Musyawarah pembentukan POKJA tersebut tidak ditentukan masa bhakti atau periode kepengurusan. Hal ini tentu saja dikarenakan 
Ilma Fatimah Yusuf, Edhi Martono, Agus Prasetya -- Peran Pemuda Dalam Pengembangan Eduwisata Energi Terbarukan Dan Implikasinya Terhadap Ketahanan Ekonomi Wilayah (Studi Di Desa Poncosari Kecamatan Srandakan Kabupaten Bantul Daerah Istimewa Yogyakarta)

masih dalam masa awal pembentukan, sehingga pembahasan belum sampai pada periode kepengurusan. Artinya, musyawarah tersebut baru hanya difokuskan pada pembentukan POKJA dan arah gerak kedepannya, yakni sebagai wadah untuk mendorong kemandirian dan produktivitas pemuda Desa Poncosari.

Pembentukan POKJA tersebut selain untuk mengakomodir warga masyarakat (pemuda), juga merupakan wujud dari pendayagunaan pemuda untuk meningkatkan produktivitasnya. Pemuda yang merupakan generasi penerus bangsa, sehingga sudah selayaknya terlibat dalam pengembangan perekonomian, sehingga peningkatan produktivitas pemuda merupakan hal yang sangat penting dalam menunjang pembangunan ekonomi suatu wilayah.

Dorongan yang dilakukan oleh PUSTEK UGM memberikan support agar pemuda semakin produktif, yang diimplementasikan dengan pembentukan POKJA eduwisata energi terbarukan pada tahun 2011. Pembangunan POKJA eduwisata energi terbarukan merupakan ide yang dikembangkan oleh pihak PUSTEK UGM, akan tetapi tanpa adanya kesediaan dan partisipasi karang taruna maka kerjasama tersebut tidak akan terwujud, sehingga kelompok kerja pun tidak akan terbentuk. Artinya, PUSTEK UGM hanya memberikan stimulus respon kepada pemuda Desa Poncosari melalui karang taruna, akan tetapi pengembangan eduwisata energi terbarukan kedepannya dapat di kelola oleh POKJA secara mandiri.

PUSTEK UGM telah memberikan pelatihan dan pendampingan terhadap POKJA dalam pengembangan eduwisata energi terbarukan. Berkaitan dengan hal tersebut, maka setelah dibentuknya POKJA Eduwisata
Energi Terbarukan pada tahun 2011, maka pada tahun 2012 PUSTEK UGM telah melakukan upaya untuk meningkatkan kapasitas organisasi dalam pengembangan eduwisata tersebut. Kegiatan tersebut tidak hanya terhenti pada tahun 2012 saja, namun pada tahun 2013 juga terdapat kegiatan yang melibatkan PUSTEK UGM.

Pembinaan dan kegiatan yang diselenggarakan tersebut sebenarnya dapat menjadi bekal bagi pemuda untuk mengembangkan potensi dalam dirinya, sehingga kemandirian dan produktifitas akan semakin berkembang. Pelatihan dan pembinaan yang digagas oleh PUSTEK UGM selama MoU berlangsung masih belum maksimal, dan sejauh ini tidak ada dampak yang signifikan bagi pemuda yang tergabung dalam POKJA eduwisata untuk semakin mandiri dan produktif dalam pengembangan eduwisata tersebut. Hal ini dapat dilihat seiring dengan berjalannya waktu terdapat seleksi alamiah ketidakaktifan pemuda dalam POKJA Desa Poncosari. Pemuda yang awalnya berjumlah 38 orang pada saat awal pembentukan, sekarang yang masih aktif hanya sekitar 15 orang.

\section{Penganekaragaman Energi Terbarukan}

Pengembangan Pembangkit Listrik Tenaga Hibrid (PLTH) dan BIOGAS yang berada di Pantai Baru Pandansimo merupakan bentuk diversifikasi energi terbarukan. Pengertian Hibrid pada umumnya adalah penggunaan dua atau lebih pembangkit listrik dengan sumber energi yang berbeda. Tujuan utama dari sistem hibrid pada dasarnya adalah berusaha menggabungkan dua atau lebih sumber energi (sistem pembangkit), yang dikombinasikan dan saling supply satu sama 
lain, sehingga ada efisiensi ekonomis pada beban tertentu. Begitupula dengan sistem kerja dari PLTH, yang mengkombinasikan antara tenaga angin, sinar matahari, diesel atau generator, kemudian dikonversi menjadi energi listrik.

Aplikasi pengembangan teknologi PLTH sebagai sistem pembangkit listrik di Pantai Baru Pandansimo merupakan hal yang sangat realistis dan tepat sasaran. Pertama, pancaran sinar matahari (tenaga surya) dan tenaga angin yang kuat menjadi modal dasar dalam pengembangan PLTH, sehingga secara ekonomis menjadi lebih efisien. Kedua, sebagai kawasan destinasi wisata yang didirikan pada Tahun 2010 silam belum ada jaringan listrik yang masuk ke sana, seperti PLN.

Energi listrik yang dihasilkan dari PLTH diharapkan dapat membantu atau mendukung aktivitas usaha yang dikembangkan oleh masyarakat yang tinggal di daerah sekitar. Listrik yang dihasikan juga digunakan untuk pengangkatan air bersih dengan menggunakan panel surya. Pemanfaatan air tersebut difungsikan untuk pengairan pertanian lahan pasir dan kolam budidaya ikan air tawar di sekitar area PLTH. Pasalnya, sistem aliran air (irigasi) di daerah tersebut tidak ada, sehingga banyak warga yang kesusahan dalam mendapatkan air untuk pengairan sawah dan kolam ikan. Adanya sistem pompa air tersebut sangat berguna bagi warga masyarakat sekitar. Pengembangan teknologi energi terbarukan juga digunakan untuk memproduksi es batu. Total produksi es batu setiap harinya menghasilkan $100 \mathrm{Kg}$, dengan inverter 7,5KW/ 120V (1 Phase).

BIOGAS dalam hal ini merupakan salah satu energi terbarukan yang telah dikembangkan dan digunakan untuk kepentingan masyarakat sekitar. BIOGAS merupakan proses kimia dari sampah organik maupun kotoran binatang (sapi) yang dikonversi menjadi energi, salah satunya sebagai bahan bakar untuk memasak. Pantai Baru Pandansimo menjadi salah satu sentra pengembangan BIOGAS di Kabupaten Bantul yang berbasiskan dari kotoran sapi dan pengelolaannya menjadi satu dengan PLTH. Pengembangan BIOGAS dari kotoran sapi digunakan sebagai bahan bakar dasar untuk memasak. Produksi BIOGAS ini disalurkan untuk bahan bakar memasak di warung (kuliner) yang ada di Pantai Baru Pandansimo. Dukungan berupa keberadaan BIOGAS di Pantai Baru Pandansimo membantu perkembangan perekonomian warga, sehingga hal ini menjadi harapan dari masing-masing pihak yang terlibat dalam pengembangan dan pemanfaatan teknologi BIOGAS tersebut.

Keberadaan PLTH dan BIOGAS selain sebagai energi alternatif juga telah dikembangkan sebagai kawasan wisata berpendidikan (eduwisata energi terbarukan). Pengembangan eduwisata tersebut telah dimotori oleh Pemuda Desa Poncosari yang tergabung dalam Kelompok Kerja (POKJA) Desa Poncosari atas dorongan PUSTEK UGM. Pengembangan energi terbarukan di Pantai Baru Pandansimo memiliki visi dan misi, yaitu untuk "mencerdaskan kehidupan bangsa melalui penguasaan energi terbarukan dengan wawasan pendidikan untuk kemakmuran masyarakat” (Data diambil dari Materi PLTH Bayu Baru Kincir Angin-Panel Surya dan BIOGAS Dinas Sumberdaya Air Kabupaten Bantul).

Eduwisata Energi Terbarukan selanjutnya sebagai objek wisata pendidikan yang berbasiskan pada pengembangan energi listrik dan BIOGAS yang disajikan bagi para wisatawan yang berkunjung bukan pada aras penggunaan aliran listrik dan BIOGAS untuk 
Ilma Fatimah Yusuf, Edhi Martono, Agus Prasetya -- Peran Pemuda Dalam Pengembangan Eduwisata Energi Terbarukan Dan Implikasinya Terhadap Ketahanan Ekonomi Wilayah (Studi Di Desa Poncosari Kecamatan Srandakan Kabupaten Bantul Daerah Istimewa Yogyakarta)

warung-warung yang ada di area pantai. Materi yang disajikan dalam wisata berpendidikan tersebut adalah tentang konversi energi surya, angin yang dikombinasikan dengan diesel menjadi energi listrik. Begitu pula kotoran sapi yang di konversi menjadi gas. Artinya proses perubahan energi tersebut yang disajikan sebagai materi wisata berpendidikan. Hal tersebut nantinya akan menjadi daya tarik bagi pengunjung yang datang, karena selain rekreasi juga mendapatkan ilmu pengetahuan tentang proses konversi energi.

Penganekaragaman energi terbarukan yang dijadikan sebagai objek wisata pendidikan telah diolah oleh POKJA eduwisata. Pemuda yang tergabung dalam POKJA eduwisata merupakan motor penggerak yang sebelumnya di dorong oleh PUSTEK UGM untuk mengembangkan keberadaan PLTH dan BIOGAS sebagai objek wisata pendidikan. Wisatawan yang berkunjung banyak yang tidak melalui POKJA eduwisata, melainkan langsung berkoordinasi dengan pihak pengelola energi terbarukan. Hal tersebut dapat terjadi karena tidak adanya koordinasi yang jelas dan terstruktur antara POKJA dengan pengelola energi terbarukan. Kondisi ini juga disebabkan oleh POKJA eduwisata yang mengalami degradasi pengembangan eduwisata tersebut, sehingga konsepsi eduwisata yang sedari dulu digagas oleh POKJA eduwisata mengalami stagnasi. Hal ini tidak mengherankan apabila ada wisatawan yang berkunjung telah dikoordinir oleh pengelola energi terbarukan.

\section{Peran Pemuda Dalam Pengembangan Eduwisata Energi Terbarukan}

Keberadaan pengembangan teknologi energi terbarukan merupakan nilai lebih yang dimiliki oleh Desa Poncosari, sehingga jika kondisi tersebut dimanfaatkan sebagai objek wisata dapat menjadi daya tarik wisatawan yang berkunjung. Karang taruna sebagai representasi pemuda Desa Poncosari telah didorong oleh PUSTEK UGM untuk mengembangkan keberadaan PLTH dan BIOGAS sebagai objek wisata pendidikan.

Dorongan pengembangan tersebut tidak pada aras pemanfaatan atau penggunaan, akan tetapi memanfaatkan keberadaan PLTH dan BIOGAS untuk dijadikan sebagai objek wisata berbasis pendidikan yang di kelola oleh POKJA eduwisata. Pelatihan dan pembinaan yang dilakukan oleh PUSTEK UGM adalah upaya untuk menyadarkan pemuda desa agar tidak menjadi pengguna atau konsumen atas keberadaan PLTH dan BIOGAS. Pemuda dalam hal ini didorong untuk dapat berpikir dan bertindak secara mandiri serta produktif dengan cara mengelola PLTH dan BIOGAS sebagai objek wisata edukatif. Pengembangan objek wisata tersebut dalam tataran implementasi sudah semestinya dikelola secara maksimal dan profesional. Hal pertama yang semestinya dilakukan adalah menyadarkan pemuda akan pentingnya pengembangan diversifikasi energi terbarukan sebagai objek wisata pendidikan.

Pengembangan eduwisata yang di kelola oleh pemuda mempunyai visi untuk "mengembangkan wisata pendidikan energi baru terbarukan”, sedangkan misi dari pengembangan eduwisata adalah : (1). Sebagai instrumen atau wahana pembelajaran bagi dunia pendidikan atau masyarakat luas baik melaui workshop kelas maupun praktek langsung terkait proses pembuatan, sistem kerja atau operasional PLTH dan BIOGAS. Maka dari itu terdapat transformasi ilmu pengetahuan terhadap masyarakat luas atau 
dunia pendidikan. (2). Mempopulerkan dan mengajak masyarakat untuk sadar akan pentingnya pengembangan energi terbarukan. (3). Membentuk pola pikir masyarakat mandiri, inovatif dan peduli lingkungan dengan cara mengembangkan teknologi energi terbarukan. (4). Mendorong penggunaan sumber energi terbarukan secara individu maupun kolektif dalam masyarakat. (5). Memajukan perekonomian masyarakat. (6). Berperan aktif dan ambil bagian dalam pemecahan masalah energi global.

Pengembangan eduwisata energi terbarukan merukapan wahana pembelajaran yang bertujuan untuk mencerdaskan masyarakat luas, dan juga dapat memperluas akan pengetahuan pada generasi muda terhadap tantangan energi di masa depan. Hal tersebut sangat menunjang dunia pendidikan, pasalnya bagi peserta didik yang ingin mempelajari pengembangan teknologi energi terbarukan tidak hanya cukup belajar dari literatur secara tekstual, akan tetapi perlu mempelajari secara kontekstual atau langsung, baik dari proses pembuatan dan sistem operasional. Selain itu, konsep pengembangan eduwisata energi terbarukan yang dijalankan oleh pemuda Desa Poncosari melalui POKJA merupakan wujud dari upaya pembangunan ekonomi desa. Pemuda yang tergabung dalam POKJA telah memainkan peranan penting dalam pengembangan objek wisata di Pantai Baru Pandansimo, khususnya yang berbasiskan pendidikan. Sosialisasi dan promosi telah diupayakan oleh pemuda untuk memperkenalkan eduwisata energi terbarukan dan keberadaan Pantai Baru Pandansimo.

Pengenalan tersebut dilakukan dalam bentuk promosi melalui penyebaran leaflet atau brosur ke masyarakat luas. Promosi juga dilakukan dengan cara kunjungan langsung ke beberapa lembaga pendidikan. Pemuda juga melakukan promosi melalui media cetak dan online untuk memperkenalkan sekaligus mempromosikan objek wisata. Kegiatan sosialisasi atau promosi yang dilakukan POKJA eduwisata ke masyarakat luas bukan sekedar memberikan informasi semata, akan tetapi terdapat penekanan bagi masyarakat luas untuk berpartisipasi dalam pengembangan diversifikasi energi terbarukan.

Pemuda tentu saja dalam melakukan promosi bertujuan agar masyarakat luas mengadakan kunjungan wisata ke lokasi disversifikasi energi terbarukan sebagai objek wisata pendidikan dan Pantai Baru Pandansimo. Posisi pemuda tidak hanya sekedar mensosialisasikan keberadaan objek wisata, namun juga menawarkan sebagai jasa pemandu wisata apabila terdapat wisatawan yang hendak mengadakan kunjungan wisata pendidikan dapat menggunakan jasa POKJA eduwisata sebagai pemandu. Tanpa adanya pemandu wisata, para wisatawan akan kebingungan dalam mempelajari sistem kerja dari PLTH dan BIOGAS. Oleh karena itu pemuda yang tergabung dalam POKJA selaku pemandu akan menjelaskan sistem operasional tersebut. Harapan pemuda sebagai pemandu wisata selain untuk memperkenalkan PLTH dan BIOGAS, juga terdapat aspek ekonomis. Artinya, pemuda sebagai pemandu wisata telah menawarkan paket-paket wisata yang harus dibayarkan oleh wisatawan yang berkunjung, dengan begitu pemuda menjadi mempunyai penghasilan.

Pengembangan eduwisata yang di kelola oleh pemuda ternyata dalam prakteknya tidak berjalan dengan lancar. Berbagai kendala telah muncul, yang kesemua itu bermuara pada 
Ilma Fatimah Yusuf, Edhi Martono, Agus Prasetya -- Peran Pemuda Dalam Pengembangan Eduwisata Energi Terbarukan Dan Implikasinya Terhadap Ketahanan Ekonomi Wilayah (Studi Di Desa Poncosari Kecamatan Srandakan Kabupaten Bantul Daerah Istimewa Yogyakarta)

stagnasi POKJA eduwisata energi terbarukan. Minimnya tingkat penghasilan merupakan faktor yang mendasari stagnasi POKJA eduwisata energi terbarukan. Minimnya tingkat penghasilan yang di peroleh pemuda telah mendorongnya untuk mencari pekerjaan lain. Ketika pemuda sudah mendapatkan pekerjaan di luar, telah berdampak pada POKJA itu sendiri. Pasalnya, orang tersebut menjadi tidak punya waktu yang cukup untuk mengelola POKJA eduwisata. Selain itu, juga tidak ada upaya yang nyata untuk mengganti pengurus yang sudah tidak lagi aktif, karena ketidakaktifan pengurus merupakan dasar dari stagnasi POKJA.

\section{Pasang Surut Eduwisata Energi Terbarukan}

Pemuda mempunyai peranan yang sangat penting dalam pembangunan negara ini. Keterlibatan pemuda bukan pada pengambil kebijakan, namun selain dapat memberikan tawaran kebijakan juga dapat ikut serta dalam suksesi pembangunan. Spirit yang tinggi menjadi modal dasar yang dimiliki pemuda, namun hal itu juga harus diiringi dengan pemikiran yang kritis dan konstruktif. Pemuda sebenarnya mempunyai peran kontrol sosial terhadap sebuah isu yang muncul di permukaan, artinya pemuda harus tanggap terhadap kondisi atau problematika yang ada. Kepekaan pemuda terhadap fenomena sosial harus selalu dilatih, oleh karena itu ruangruang aktualisasi diri harus diwujudkan, salah satunya melalui organisasi.

Organisasi merupakan wadah pembentukan karakter pemuda khususnya, bahkan menjadi ruang relasi pencipta nilainilai baru dalam kehidupan bermasyarakat. Peranan pemuda dalam kehidupan masyarakat melalui organisasi sangatlah penting, tidak hanya sekedar mendidik para anggota, namun peranan pemuda melalui organisasi juga mempunyai kedudukan dalam masyarakat untuk turut serta memajukan perekonomian. Intensitas pemuda dalam organisasi seringkali mengalami pasang surut, baik disebabkan oleh kondisi internal maupun adanya faktor eksternal. Pemuda dalam hal ini sudah selayaknya melalui perangkat organisasi berpartisipasi aktif dalam pembangunan sumber daya manusia dan pengembangan ekonomi wilayah. Hal ini tentu saja dengan cara mendorong pemuda dan masyarakat luas untuk meningkatkan produktivitas dan kemandirian ekonomi.

Wujud dari produktivitas dan kemandirian ekonomi yang telah dijalankan oleh pemuda Desa Poncosari adalah denganmengembangkan pengelolaan PLTH dan BIOGAS sebagai objek wisata pendidikan. Konsep pengembangan eduwisata energi terbarukan yang dijalankan oleh pemuda Desa Poncosari melalui POKJA merupakan wujud dari upaya pembangunan ekonomi desa. Pemuda yang tergabung dalam POKJA telah memainkan peranan penting dalam pengembangan objek wisata di Pantai Baru Pandansimo, khususnya yang berbasiskan pendidikan. Sosialisasi dan promosi telah diupayakan oleh pemuda untuk memperkenalkan eduwisata energi terbarukan dan keberadaan Pantai Baru Pandansimo.

Pengenalan tersebut dilakukan dalam bentuk promosi melalui penyebaran leaflet atau brosur ke masyarakat luas. Promosi juga dilakukan dengan cara kunjungan langsung ke beberapa lembaga pendidikan. Pemuda juga melakukan promosi melalui media cetak dan online untuk memperkenalkan sekaligus mempromosikan objek wisata. Kegiatan 
sosialisasi atau promosi yang dilakukan POKJA eduwisata ke masyarakat luas bukan sekedar memberikan informasi semata, akan tetapi terdapat penekanan bagi masyarakat luas untuk berpartisipasi dalam pengembangan diversifikasi energi terbarukan.

Pemuda tentu saja dalam melakukan promosi bertujuan agar masyarakat luas mengadakan kunjungan wisata ke lokasi diversifikasi energi terbarukan sebagai objek wisata pendidikan dan Pantai Baru Pandansimo. Posisi pemuda tidak hanya sekedar mensosialisasikan keberadaan objek wisata, namun juga menawarkan sebagai jasa pemandu wisata apabila terdapat wisatawan yang hendak mengadakan kunjungan wisata pendidikan dapat menggunakan jasa POKJA eduwisata sebagai pemandu. Tanpa adanya pemandu wisata, para wisatawan akan kebingungan dalam mempelajari sistem kerja dari PLTH dan BIOGAS, oleh karena itu pemuda yang tergabung dalam POKJA selaku pemandu akan menjelaskan sistem operasional tersebut. Harapan pemuda sebagai pemandu wisata selain untuk memperkenalkan PLTH dan BIOGAS, juga terdapat aspek ekonomis. Artinya, pemuda sebagai pemandu wisata telah menawarkan paket-paket wisata yang harus dibayarkan oleh wisatawan yang berkunjung, dengan begitu pemuda menjadi mempunyai penghasilan.

Berkaitan dengan faktor ekonomis, tentu saja pemuda dalam sosialisasi atau promosi yang dilakukan seharusnya berjalan secara rutin dan juga berkesinambungan. Apabila promosi dilakukan pemuda secara berkala, maka semakin luas pula informasi yang akan diterima masyarakat, dengan begitu semakin dikenal pula objek wisata pendidikan tersebut. Kondisi tersebut nantinya akan berimbas pada banyak wisatawan yang menggunakan jasa POKJA eduwisata sebagai pemandu, dengan begitu penghasilan pemuda akan semakin meningkat. Harapan dan kenyataan tidak berjalan secara linier, terdapat kontradiktif peran pemuda dalam pengembangan eduwisata energi terbarukan. Pasang surut pengembangan eduwisata yang diperankan oleh pemuda semakin tidak terhindarkan, bahkan hal tersebut berujung pada stagnasi.

Pemuda yang di dorong oleh PUSTEK UGM mempunyai spirit yang tinggi dalam membangun dan mengembangkan eduwisata energi terbarukan. Hal ini dapat dilihat dari berbagai program dan kegiatan yang telah diselenggarakan, baik dalam bentuk promosi maupun mengadakan event dalam bentuk konser musik. Semua program dan kegiatan yang telah diselenggarakan oleh pemuda berkaitan dengan eduwisata energi terbarukan. Artinya, program dan kegiatan tersebut sebagai instrumen selain untuk mempererat hubungan internal POKJA, namun juga untuk mengkampanyekan eduwisata dan menunjukan eksistensinya. Muara dari program dan kegiatan tentu saja yang telah diselenggarakan tersebut bertujuan agar eduwisata energi terbarukan semakin dikenal dan semakin banyak wisatawan yang berkunjung dengan menggunakan jasa POKJA sebagai pemandu wisata, sehingga tingkat penghasilan pemuda pun semakin meningkat.

Semangat pemuda seiring dengan berjalannya waktu mengalami pasang surut, bahkan menurun, sehingga POKJA eduwisata menuai stagnasi. Sosialisasi dan promosi tidak dilakukan secara berkala, bahkan kini telah terhenti. Sosialisasi dan promosi yang dilakukan ke instansi pendidikan hanya di 
Ilma Fatimah Yusuf, Edhi Martono, Agus Prasetya -- Peran Pemuda Dalam Pengembangan Eduwisata Energi Terbarukan Dan Implikasinya Terhadap Ketahanan Ekonomi Wilayah (Studi Di Desa Poncosari Kecamatan Srandakan Kabupaten Bantul Daerah Istimewa Yogyakarta)

awal pembentukan POKJA eduwisata, dan tidak adanya jadwal pelaksanaan sosialisasi secara rutin.

Sosialisasi dan promosi yang dilakukan oleh POKJA eduwisata hanya ke instansi pendidikan (sekolah) di daerah Kabupaten Bantul saja, bahkan paling banyak di Kecamatan Srandakan. Sosialisasi tersebut hanya dilakukan pada tahun 2012-2013 saja, sedangkan pada tahun-tahun berikutnya tidak ada sosialisasi ke instansi pendidikan. Pemuda kurang serius dalam pengembangan eduwisata terlihat dengan tidak adanya agenda sosialisasi secara rutin dan masih minimnya jangkauan promosi yang dilakukan oleh POKJA eduwisata. Sosialisasi dan promosi seharusnya ke lembaga pendidikan dilakukan secara berkelanjutan atau terjadwal, misal satu bulan sekali dan tidak hanya di awal pembentukan POKJA, namun berkesinambungan.

Sosialisasi ke lembaga pendidikan yang dilakukan oleh POKJA eduwisata masih kurang maksimal, namun terdapat upaya lain, yakni penyebaran brosur dan leaflet dan promosi melalui media cetak maupun online. Menurut pemaparan Nukman selaku ketua POKJA, promosi dengan cara seperti ini pun tidak dilakukan secara maksimal, hanya beberapa anggota saja yang melakukan penyebaran brosur, itupun tidak terukur dan terjadwal (hasil wawancara, 29 Februari 2016).

POKJA eduwisata juga mengadakan beberapa kegiatan sebagai instrumen kampanye keberadaan eduwisata energi terbarukan, selain promosi secara langsung maupun melalui media. Adapun bentuk kegiatan yang pernah diselenggarakan oleh POKJA eduwisata energi terbarukan adalah sebagai berikut:

Pertama, kegiatan Outbound Training, yang dilaksanakan pada tanggal 25 Maret
2012, dengan dihadiri oleh 80 orang peserta, yang terdiri dari unsur POKJA eduwisata, karang taruna desa dan dusun. Kegiatan ini bertujuan untuk mempererat hubungan pemuda yang tergabung dalam POKJA eduwisata energi terbarukan. Bahkan kegiatan ini tidak lepas dari promosi, yaitu memperkenalkan eduwisata energi terbarukan yang kepada masyarakat luas.

Kedua, mengadakan lomba kincir angin tingkat nasional pada Tahun 2012 yang diselenggarakan oleh POKJA eduwisata bekerjasama dengan pengelola PLTH dan BIOGAS. Perlombaan tersebut bertujuan untuk menunjukan eksistensi keberadaan diversifikasi energi terbarukan untuk semakin di kenal masyarakat luas, sehingga harapannya banyak wisatawan yang berkunjung.

Ketiga, Talk Show di RRI dilaksanakan pada awal Bulan April 2013 yang diikuti oleh Komunitas Earth Hour Jogja dan POKJA Eduwisata Poncosari. Acara tersebut merupakan wujud dari sosialisasi rencana kegiatan yang akan diselenggarakan di Pantai Baru Pandansimo, yaitu mengadakan konser musik dengan tema "Energi Baru, Suara Baru”.

Keempat, mengadakan konser musik “Energi Baru, Suara Baru” merupakan tindak lanjut dari Talk Show yang dilakukan sebelumnya. Kegiatan konser musik tersebut telah diselenggarakan pada tanggal 28 April 2013. Konser musik dengan tema "Energi Baru, Suara Baru” selain sebagai media promosi, juga mengajak masyarakat luas akan pentingnya pemanfaatan energi terbarukan yang ramah lingkungan.

Kelima, pameran dan ekspose POKJA eduwisata yang diselenggarakan pada tahun 2013. Kegiatan ini merupakan peringatan 
sewindu wafatnya Prof. Mubyarto, yang dihadiri oleh pengurus POKJA, mahasiswa, dan masyarakat umum. Adapun tujuan dari kegiatan ini adalah untuk mensosialisasikan kegiatan POKJA Eduwisata pada generasi muda, dan memperkenalkan paket-paket eduwisata.

Keenam, kegiatan penguatan kelembagaan POKJA eduwisata melalui pendalaman pengetahuan energi terbarukan, manajemen wisata dan membangun jejaring yang dilaksanakan pada tahun 2013. Kegiatan ini ditujukan untuk pemuda yang tergabung dalam POKJA eduwisata agar manajemen keorganisasian semakin matang. Adapun aktivitas kegiatan tersebut meliputi pendalaman pengetahuan aplikasi energi terbarukan, manajemen eduwisata energi terbarukan dan teknik membangun jaringan yang bertujuan untuk pengembangan eduwisata.

Ketujuh, Semiloka Eduwisata Energi Poncosari yang dihadiri oleh pengurus POKJA eduwisata dan pengurus Karang Taruna seKabupaten Bantul (25 orang) diselenggarakan pada tanggal 8 Desember 2013. Tujuan dari diadakannya kegiatan ini adalah selain untuk mensosialisasikan keberadaan eduwisata energi terbarukan juga pre-launching paket wisata.

Pemuda yang tergabung dalam Kelompok Kerja (POKJA), pada tahun 2012-2013 terlihat antusias dalam pengembangan eduwisata energi terbarukan, hal ini dapat dilihat dari program dan kegiatan yang telah di selenggarakan. Akan tetapi memasuki tahun 2014, semangat pemuda telah mengalami penurunan, meskipun di tahun 2015 terdapat usaha untuk membangkitkan semangat pemuda. Hal ini dapat dilihat dari keikutsertaan Karang Taruna Desa Poncosari dalam perlombaan karang taruna tingkat kabupaten. Karang Taruna Desa Poncosari dalam acara perlombaan tersebut telah mengusung tema "Energi Terbarukan”, dan mendapat juara tiga. Harapannya dengan mengikuti acara perlombaan tersebut dapat menjadi stimulus pemuda untuk mengaktifkan kembali POKJA eduwisata. Namun kenyataan berkata lain, POKJA eduwisata tetap saja mengalami stagnasi, dengan di tandai tidak adanya program dan kegiatan yang di selenggarakan.

Peran POKJA dalam pengembangan eduwisata tersebut di rasa tidak mempunyai dampak yang signifikan, akan tetapi promosi yang mereka lakukan menjadi sumbangsih semakin dikenalnya Pantai Baru Pandansimo, sebagai wisata edukasi maupun wisata alam. Pasalnya promosi yang dilakukan oleh POKJA, tidak hanya keberadaan PLTH dan BIOGAS sebagai pengembangan teknologi energi terbarukan, akan tetapi promosi tersebut juga memperkenalkan keberadaan wisata Pantai Baru Pandansimo dan Konservasi Penyu Lekang (Lepidochelys olivacea). Dikenalnya Pantai Baru Pandansimo dapat dilihat dari peningkatan jumlah pengunjung yang datang ke lokasi wisata tersebut. Peningkatan jumlah pengunjung (wisatawan) ke Pantai Baru Pandansimo dari tahun ke tahun dapat dilihat pada grafik 1 .

Grafik 1 tersebut menunjukkan bahwa terdapat peningkatan jumlah wisatawan yang berkunjung di Pantai Baru Pandansimo cukup signifikan dari tahun 2011 sebesar 42.630 orang ke tahun 2015 sebesar 458.514 orang. Jumlah wisatawan pada tahun 2015 yang berkunjung mengalami peningkatan secara drastis apabila dibandingkan dengan tahun sebelumnya. Banyak faktor yang mempengaruhi peningkatan jumlah wisatawan 
Ilma Fatimah Yusuf, Edhi Martono, Agus Prasetya -- Peran Pemuda Dalam Pengembangan Eduwisata Energi Terbarukan Dan Implikasinya Terhadap Ketahanan Ekonomi Wilayah (Studi Di Desa Poncosari Kecamatan Srandakan Kabupaten Bantul Daerah Istimewa Yogyakarta)

Grafik 1

Data Pengunjung Pantai Baru Pandansimo

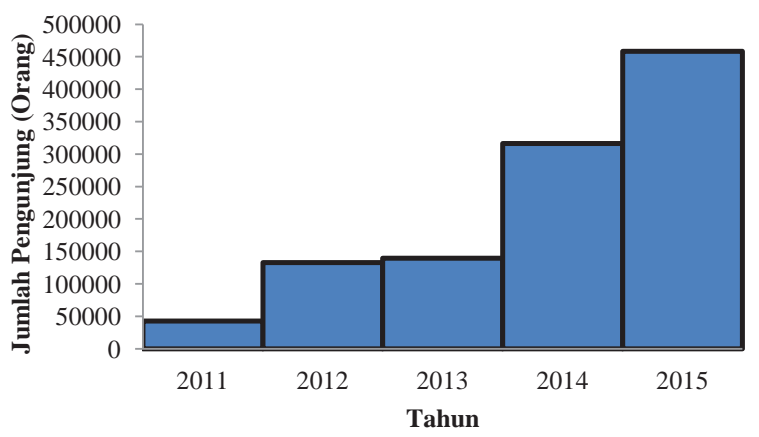

Sumber : Data Kunjungan Wisata Pantai Baru Tahun 2011-2015.

yang berkunjung. Salah satunya adalah promosi yang dilakukan oleh POKJA eduwisata.

Adanya promosi yang dilakukan POKJA telah menjadikan Pantai Baru Pandansimo semakin ramai dikunjungi wisatawan. Hal ini merupakan sebuah peluang besar bagi masyarakat sekitar untuk menambah penghasilan, salah satunya dengan membuka warung kuliner ataupun juru parkir dan bidang jasa yang lain. POKJA eduwisata itu sendiri justru malah mengalami stagnasi. Tidak adanya aktivitas kegiatan sejak tahun 2014 secara konkret dan berkala merupakan sebuah penanda ketidakaktifan POKJA eduwisata. Bahkan dulunya, Pemerintah Desa Poncosari telah menyediakan ruangan untuk kesekretariatan (kantor) POKJA eduwisata, namun kini kantor tersebut sudah tidak ada lagi. Hal ini di sebabkan oleh ketidakaktifannya POKJA eduwisata, sehingga kantor tersebut pun tidak lagi digunakan, oleh karena itu pemerintah desa telah mencabut fasilitas (kantor) tersebut (Supriyanto: Kepala Desa Poncosari, 03 Maret 2016).

Mengacu pada pemaparan yang disampaikan oleh Pak Mur dan Pak Arif selaku pengelola (karyawan) PLTH dan BIOGAS dalam 1 tahun terakhir terdapat sekitar
5.000 orang yang mengadakan kunjungan wisata pendidikan (Wawancara, 29 Februari 2016). Wisatawan yang berkunjung ke lokasi diversifikasi energi terbarukan tidak menggunakan jasa POKJA, melainkan langsung berkoordinasi dengan pengelola PLTH dan BIOGAS. Wisatawan yang mengadakan kunjungan wisata pendidikan tersebut dari berbagai instansi pendidikan, baik tingkatan sekolah dasar hingga ke perguruan tinggi. Bahkan kunjungan wisata pendidikan tersebut tidak hanya lembaga pendidikan yang dari berasal dari Yogyakarta. Berkaitan dengan hal tersebut, tetap ada beberapa wisatawan yang berkunjung dengan menggunakan jasa POKJA, namun jumlahnya tidak terlalu banyak. Selama POKJA eduwisata didirikan, hanya sekitar kurang lebih 1.000 orang yang menggunakan jasa POKJA sebagai pemandu wisata (Nukman: Ketua POKJA Eduwisata Energi Terbarukan, 29 Februari 2016).

Hal ini menjadi sangat ironis, ketika di satu sisi semakin banyak wisatawan yang berkunjung ke lokasi wisata tersebut, namun di sisi lain POKJA eduwisata malah mengalami stagnasi. Bahkan wisatawan yang menggunakan jasa POKJA sebagai pemandu wisata pun jumlahnya tidak terlalu banyak. Tentu saja hal ini disebabkan oleh kondisi POKJA eduwisata yang mengalami stagnasi, sehingga wisatawan yang hendak mengadakan kunjungan tidak menggunakan jasa POKJA. Stagnasi POKJA eduwisata tentu saja tidak lahir dari ruang kosong, akan tetapi terdapat berbagai faktor atau kendala yang menyebabkan kondisi tersebut terjadi. Penyebabnya baik itu oleh kondisi internal POKJA maupun adanya faktor eksternal yang memperkuat POKJA untuk semakin stagnan. 


\section{Kendala POKJA Eduwisata Energi Terbarukan}

Pengelolaan organisasi atau pengembangan suatu usaha tentu saja dalam perjalanannya banyak menuai kendala ataupun hambatan. Kendala yang muncul apabila tidak segara diatasi maka dapat menyebabkan stagnasi atau kemandegan. Terlebih jika itu berbasis atau berorientasi pada profit, kondisi stagnan dapat berakibat kehilangan segmentasi pasar yang pada akhirnya mengharuskan usaha tersebut untuk gulung tikar. Kendala yang muncul dapat disebabkan oleh faktor internal maupun eksternal, yang keduanya saling berkaitan satu sama lain. Menurut peneliti, faktor (kondisi) internal merupakan determinasi dari kemandegan sebuah usaha, sedangkan kondisi ekternal merupakan faktor pendorong.

Begitupun dengan pengembangan eduwisata energi terbarukan juga tengah mengalami suatu kendala, yaitu kondisi yang stagnan. Kondisi internal POKJA eduwisata merupakan faktor dasar yang menyebabkan pengembangan eduwisata energi terbarukan mengalami stagnasi, sedangkan faktor eksternal yang menjadi pendorong sekaligus penguat stagnasi pengembangan eduwisata energi terbarukan dimaksud. Beberapa faktor yang menyebabkan kondisi tersebut terjadi, yaitu:

Pertama, pemuda yang tergabung dalam POKJA eduwisata kurang serius dan konsisten dalam pengembangan eduwisata energi terbarukan. Salah satunya adalah dari segi promosi yang dilakukan tidak berjalan secara maksimal dan berkesinambungan, baik secara langsung ataupun melalui media yang berbasis cetak maupun online. Promosi sudah dilakukan, namun masih kurang maksimal, sehingga dampak untuk POKJA belum signifikan. Hal ini sesuai dengan pernyataan dari Nukman selaku ketua POKJA eduwisata energi terbarukan, bahwa sosialisasi dan promosi yang dilakukan pemuda tidak berjalan secara berkala atau rutin (Wawancara, 19 Februari 2016). Wujud lain dari kurang seriusnya POKJA eduwisata energi terbarukan dalam pengembangannya tidak adanya upaya pendaftaran ke Dinas Pariwisata terkait objek wisata tersebut.

Pemuda yang tergabung dalam POKJA eduwisata diawal pendirian pada dasarnya menunjukan sebuah keseriusan. Hal ini dapat dilihat dari antusias pemuda dalam mengikuti kegiatan-kegiatan yang telah diselenggarakan, baik berupa event maupun pelatihan ataupun pembinaan yang dilakukan oleh PUSTEK UGM. Hal serupa juga dibenarkan oleh Nukman selaku Ketua POKJA, bahwa para pemuda mempunyai antusias dan spirit dalam pengembangan eduwisata energi terbarukan, akan tetapi seiring berjalannya waktu, antusias dan spirit tersebut mulai menurun. Hal ini disebabkan oleh minimnya tingkat penghasilan yang di peroleh, sehingga mereka beralih atau mencari pekerjaan yang lain. Pemuda pada dasarnya mempunyai pekerjaan yang lain, namun jika mereka mempunyai konsistensi dalam pengembangan eduwisata tersebut, maka kemungkinan stagnasi akan kecil. Menurut peneliti, ketidakseriusan tersebut erat kaitannya dengan kesadaran, sehingga komitmen dan konsistensi dalam pengembangan eduwisata mengalami stagnasi.

Kedua, penghasilan yang diperoleh dari pengembangan eduwisata energi terbarukan masih belum signifikan. Minimnya penghasilan yang diperoleh menyebabkan semangat pemuda mengalami penurunan dalam pengembangan 
Ilma Fatimah Yusuf, Edhi Martono, Agus Prasetya -- Peran Pemuda Dalam Pengembangan Eduwisata Energi Terbarukan Dan Implikasinya Terhadap Ketahanan Ekonomi Wilayah (Studi Di Desa Poncosari Kecamatan Srandakan Kabupaten Bantul Daerah Istimewa Yogyakarta)

eduwisata tersebut. Semangat pemuda pada tahun 2015 mengalami peningkatan, namun ironisnya hal tersebut tidak berjalan secara berkesinambungan, pasalnya spirit tersebut mengalami penurunan kembali. Kondisi tersebut disebabkan oleh jumlah wisatawan yang menggunakan jasa POKJA tidak terlalu banyak, sehingga berdampak pada penghasilan yang mereka peroleh juga tidak banyak. Hal itu disebabkan oleh banyaknya wisatawan yang berkunjung tidak menggunakan jasa POKJA eduwisata, melainkan langsung berkomunikasi dan berkoordinasi dengan pengelola energi terbarukan (PLTH dan BIOGAS). Hal tersebut berakibat pada omset dari wisatawan yang berkunjung ke objek wisata pendidikan tidak menjadi penghasilan pemuda yang tergabung dalam POKJA, melainkan ke pengelola PLTH dan BIOGAS.

Ketiga, kesibukan kerja atau adanya aktivitas di luar dari masing-masing pemuda yang tergabung dalam Kelompok Kerja Desa Poncosari. Menurut asumsi peneliti, kesibukan kerja di luar, juga disebabkan oleh tingkat penghasilan yang minim dari pengembangan eduwisata energi terbarukan. Kondisi tersebut telah mendorong pemuda mencari pekerjaan lain dengan penghasilan yang pasti dan cukup. Pasalnya jika hanya mengandalkan pada penghasilan dari pengembangan eduwisata saja tidak cukup untuk menunjang kebutuhan hidup sehari-hari. Pemuda yang tergabung dalam POKJA eduwisata telah sibuk bekerja, sehingga pengembangan eduwisata tidak berjalan dengan maksimal. Terlebih hal itu juga ditunjang oleh tidak adanya pergantian pengurus POKJA yang tengah sibuk dengan pekerjaannya.

Keempat, menurunnya spirit pemuda yang tergabung dalam POKJA juga disebabkan tidak adanya lagi keterlibatan PUSTEK UGM dalam pengembangan konsep eduwisata energi terbarukan. Semenjak tidak adanya dorongan atau motivasi dari PUSTEK UGM, semangat pemuda dalam pengembangan eduwisata tersebut mengalami penurunan dan berdampak pada stagnasi POKJA eduwisata. Terhentinya kerjasama dengan PUSTEK UGM juga membuat bantuan dari BAPPEDA Kabupaten Bantul ikut terhenti. Stagnasi POKJA eduwisata terjadi paska tidak adanya dorongan dari Pusat Studi Ekonomi Kerakyatan UGM, namun bukan berarti ada atau tidak adanya lagi dorongan dari PUSTEK UGM bukanlah faktor yang mendasar.

Pembentukan POKJA eduwisata energi terbarukan yang dilakukan PUSTEK UGM apabila telah menganalisis dan mempertimbangkan kondisi sosial dan psikologis pemuda yang masuk sebagai pengurus POKJA dapat dimungkinkan tidak terjadi stagnasi pengembangan eduwisata. Artinya kondisi sosial dan psikologis seseorang akan berpengaruh dalam sebuah ruang relasi organisasi (POKJA eduwisata). Hal ini tentu saja mempunyai kaitan dengan kesadaran, komitmen dan konsistensi seseorang untuk mengaktualisasikan diri dalam ruang relasi POKJA eduwisata.

Berkaitan dengan dorongan dari PUSTEK UGM yang bukan sebagai faktor yang mendasar, namun sebagai faktor ekternal yang dapat mengkondisikan atau mendorong keaktifan pemudadalampengembanganeduwisata. Penentu dasar berjalan atau tidaknya pengembangan eduwisata ditentukan oleh kondisi atau faktor internal. Faktor internal yang menyebabkan pengembangan eduwisata mengalami stagnasi atau tidak berjalan, seperti yang sudah diulas pada alinea di atas. 
Kelima, tidak adanya hubungan koordinasi yang jelas atau terstruktur antara POKJA eduwisata dengan pihak pengelola PLTH dan BIOGAS serta pengurus POGIAT Dusun Ngentak. Hal ini pada dasarnya disebabkan oleh adanya konflik antara POGIAT Dusun Ngentak dengan Karang Taruna Desa Poncosari maupun POKJA Eduwisata. Hal ini berawal dari proses pembentukan POKJA Eduwisata energi terbarukan, yang sebenarnya ingin dikelola oleh POGIAT Dusun Ngentak. PUSTEK UGM awalnya pada sudah berkomunikasi dengan POGIAT Dusun Ngentak untuk mengembangkan PLTH dan BIOGAS sebagai objek wisata pendidikan, sebelum pembentukan POKJA eduwisata. Ide yang ditawarkan oleh PUSTEK UGM sebenarnya telah disetujui oleh pengurus POGIAT, akan tetapi seiring dengan berjalannya waktu PUSTEK UGM tidak menggandeng pengurus POGIAT, melainkan bekerjasama dengan karang taruna desa untuk membentuk POKJA eduwisata energi terbarukan dan tidak mengajak POGIAT dalam sebuah pembahasan lebih lanjut mengenai rencana pengembangan eduwisata tersebut (Suwandi: ketua POGIAT Dusun Ngentak, 15 April 2016).

Hal tersebut telah memicu kekecewaan dari pihak POGIAT Dusun Ngentak, sehingga ketika ada kunjungan wisata pendidikan di lokasi PLTH dan BIOGAS tidak dilibatkannya POKJAeduwisata. Pasalnya sebagian pengelola PLTH dan BIOGAS adalah masyarakat Dusun Ngentak, sehingga mereka menjadi bagian dari POGIAT. Berkaitan dengan hal tersebut, POKJA juga tidak dilibatkan dalam pengelolaan Pantai Baru Pandansimo, namun melibatkan masyarakat yang tinggal di sekitar Pantai Baru Pandansimo di wilayah Dusun Ngentak, sehingga sudah selayaknya pengelolaan Pantai Baru Pandansimo di kelola oleh masyarakat dusun setempat. Komunikasi yang kurang baik dan kurang lancar lebih lanjut yang dilakukan oleh POKJA eduwisata terhadap pengurus POGIAT Dusun Ngentak menjadi kendala pemuda dalam pengembangan eduwisata energi terbarukan.

Berbagai kendala yang sudah dipaparkan di atas menjadi faktor ketidakaktifan POKJA eduwisata yang bermuara pada stagnasi, maka dari itu perlu sebuah upaya solusi untuk mengatasi perihal tersebut. Sedari awal sudah pernah diadakan upaya untuk menghidupkan kembali POKJA eduwisata, yakni dilakukan langsung oleh Ketua POKJA dengan cara mengumpulkan anggotanya untuk membahas perihal stagnasi POKJA eduwisata. Menurut Nukman selaku ketua POKJA, terdapat antusias pengurus untuk menghidupkan kembali eduwisata tersebut, akan tetapi paska pembahasan atau rapat POKJA terkait refleksi eduwisata, tidak ada langkah pembenahan secara konkret dan serius.

Menurut Nukman, pemuda yang tergabung dalam POKJA kembali disibukkan dengan agenda masing-masing, dan ketika dikumpulkan kembali banyak yang tidak hadir. Upaya yang dilakukan Nukman selaku Ketua POKJA yang notabene sebagai motor penggerak bagi anggotanya sebenarnya masih belum maksimal. Hal ini di landasi dalam pembahasan refleksi POKJA eduwisata hanya dilaksanakan sekali, dan setelah itu tidak ada tindak lanjut yang konkret, misalnya mengganti pengurus POKJA yang sudah tidak lagi bersedia untuk mengelola eduwisata energi terbarukan. Artinya, tidak hanya sekedar refleksi saja, namun perlu adanya pergantian pengurus yang sudah tidak lagi bersedia untuk menjalankan kerja-kerja pengembangan eduwisata tersebut. 
Ilma Fatimah Yusuf, Edhi Martono, Agus Prasetya -- Peran Pemuda Dalam Pengembangan Eduwisata Energi Terbarukan Dan Implikasinya Terhadap Ketahanan Ekonomi Wilayah (Studi Di Desa Poncosari Kecamatan Srandakan Kabupaten Bantul Daerah Istimewa Yogyakarta)

Pemuda yang tergabung dalam POKJA eduwisata memiliki upaya untuk menghidupkan POKJA eduwisata, namun dari pihak POKJA sendiri tidak ada upaya komunikasi dengan pihak POGIAT Dusun Ngentak untuk membicarakan secara bersama terkait eduwisata energi terbarukan tersebut. POKJA seharusnya mengajak POGIAT Dusun Ngentak untuk mengadakan kerjasama tentang pengembangan PLTH dan BIOGAS sebagai objek wisata pendidikan. Menurut asumsi peneliti, jika ada komunikasi dan kerjasama antara POKJA dan POGIAT dalam pengembangan eduwisata energi terbarukan akan dimungkinkan dapat berkembang. Kondisi ini dapat terjadi karena hampir keseluruhan dari anggota POGIAT menjadi pengelola Pantai Baru Pandansimo, baik sebagai jasa tukang parkir, retribusi tiket, kuliner makanan dan pengelola PLTH dan BIOGAS. Apabila kerjasama terjalin tersebut terjalin, maka eduwisata energi terbarukan tidak akan mengalami stagnasi.

\section{Implikasinya Terhadap Ketahanan Ekonomi Wilayah}

Ketahanan ekonomi merupakan kondisi kehidupan perekonomian bangsa yang berlandaskan pada demokrasi Pancasila (Tarmidi, 1992). Ketahanan ekonomi juga mengandung kemampuan untuk memelihara stabilitas ekonomi yang sehat dan dinamis, serta mampu menciptakan kemandirian ekonomi nasional dengan daya saing yang tinggi sehingga kemakmuran rakyat yang adil dan merata dapat terwujud. Mengacu pada pendapat Francois Perroux-pertumbuhan ekonomi suatu daerah ditopang oleh adanya pusat pertumbuhan (growth pole). Pembangunan atau pertumbuhan ekonomi tidak terjadi di segala tata ruang, akan tetapi hanya terbatas pada beberapa tempat tertentu dengan komponen-komponen yang berbeda intensitasnya.

Secara fungsional, suatu lokasi konsentrasi usaha atau cabang industri yang sifatnya memiliki unsur-unsur yang bersifat dinamis mampu menstimulasi kehidupan ekonomi. Pantai Baru Pandansimo sebagai tempat wisata telah memberi stimulus kepada masyarakat sekitar untuk mengembangkan suatu usaha. Salah satunya adalah usaha yang bergerak di bidang jasa, yaitu jasa parkir, pemandu wisata dan kuliner makanan, selain itu juga terdapatnya pengembangan eduwisata energi terbarukan (PLTH, BIOGAS dan Koservasi Penyu Lekang (Lepidochelys olivacea)). Secara geografis keberadaan Pantai Baru telah menunjang dan menjadi pusat atau daya tarik penyebab terdapatnya pengembangan usaha. Konsekuensi logis dari pengembangan usaha di Pantai Baru Pandansimo telah memberikan lapangan pekerjaan bagi masyarakat setempat, sehingga mereka menjadi mempunyai penghasilan.

Terlebih dengan dijadikannya pengembangan teknologi energi terbarukan (PLTH dan BIOGAS) sebagai objek wisata pendidikan dapat menjadi daya tarik bagi wisatawan untuk berkunjung. Semakin banyak wisatawan yang berkunjung, semakin tinggi pula tingkat penghasilan masyarakat setempat, sehingga hal ini merupakan dasar dari terwujudnya ketahanan ekonomi wilayah. Kendatipun, pengembangan eduwisata energy terbarukan mengalami stagnasi, namun hal ini tidak berpengaruh kepada wisatawan yang berkunjung. Jika kita mengacu pada data kunjungan wisatawan di Pantai Baru telah mengalami peningkatan, dimana pada tahun 
2013 jumlah wisatawan yang berkunjung sejumlah 139.606 orang. Kemudian pada tahun 2014, jumlah wisatawan yang berkunjung sejumlah 316.130 orang, sedangkan pada tahun 2015 terdapat 458.514 orang yang mengadakan kunjungan wisata di Pantai Baru Pandansimo.

Meningkatnya jumlah kunjungan wisatawan di Pantai Baru Pandansimo tidak lepas dari peran pemuda yang mempromosikan keberadaan objek wisata tersebut. Pasalnya, pemuda tidak hanya mempromosikan eduwisata saja, namun Pantai Baru sebagai objek wisata juga telah di promosikan kepada masyarakat luas. Dampak dari promosi yang di lakukan oleh pemuda tersebut telah menjadikan dikenalnya Pantai Baru Pandansimo yang di dalamnya terdapat eduwisata energi terbarukan. Maka konsekuensi logis dari peningkatan jumlah kunjungan wisata tersebut adalah meningkatnya penghasilan masyarakat sekitar.

Peningkatan penghasilan masyarakat sekitar adalah dengan menjadikan objek wisata tersebut sebagai tempat untuk berjualan makanan kuliner, jasa parkir, retribusi (tiket masuk) dan jasa pemandu wisata.

Bahkan penghasilan dari warga masyarakat yang membuka usaha warung kuliner dalam satu minggu memperoleh sekitar Rp 2.000.000,00, sehingga dalam satu bulan akan memperoleh penghasilan sekitar Rp 8.000.000,00. Dari jumlah penghasilan tersebut, keuntungan (profit) yang di peroleh adalah sejumlah Rp 2.000.000,00, sedangkan untuk memenuhi kebutuhan hidup seharihari adalah sejumlah Rp 900.000,00, maka warga masyarakat yang membuka warung kuliner masih bisa menabung sejumlah Rp 1.100.000,00. Bahkan profit yang di peroleh warga dari hasil jualan makanan masih di atas Upah Minimum Regional (UMR) Kabupaten Bantul, yaitu sejumlah Rp 1.300.000,00. Belum lagi jika penghasilan keluarga di tambah dari hasil usaha yang lain, misalnya dari hasil pertanian maupun peternakan ataupu yang lain.

Maka dengan adanya pengembangan eduwisata energi terbarukan yang telah dipromosikan oleh pemuda sekaligus mempromosikan Pantai Baru telah berdampak pada peningkatan penghasilan warga sekitar. Pasalnya dengan semakin tinggi tingkat penghasilan warga akan berpengaruh terhadap kesejahteraan masyarakat. Meningkatnya penghasilan warga, merupakan sebuah petanda dari terwujudnya ketahanan ekonomi wilayah.

\section{SIMPULAN}

Berdasar penjelasan tersebut di atas dapat ditarik simpulan sebagai berikut.

Pertama, peran pemuda yang tergabung dalam POKJA eduwisata telah melakukan promosi kepada masyarakat luas maupun dunia pendidikan. Promosi yang dilakukan pemuda secara langsung, yakni berkunjung langsung dan memberikan tawaran paket wisata ke sekolah-sekolah atau dengan cara menyebar brosur. Promosi tidak langsung dalam hal ini yaitu promosi melalui media massa, baik cetak maupun berbasis online.

Promosi eduwisata yang dilakukan pemuda tidak berjalan secara rutin atau berkala, sehingga banyak wisatawan yang berkunjung langsung berkoordinasi dengan pihak PLTH dan BIOGAS. Hal ini akhirnya berdampak pada pendapatan pemuda yang tidak banyak, karena wisatawan yang menggunakan jasa POKJA hanya sedikit. Pada dasarnya kondisi tersebut 
Ilma Fatimah Yusuf, Edhi Martono, Agus Prasetya -- Peran Pemuda Dalam Pengembangan Eduwisata Energi Terbarukan Dan Implikasinya Terhadap Ketahanan Ekonomi Wilayah (Studi Di Desa Poncosari Kecamatan Srandakan Kabupaten Bantul Daerah Istimewa Yogyakarta)

disebabkan oleh tidak adanya komunikasi dan koordinasi antara POKJA eduwisata dengan pengelola PLTH dan BIOGAS, yang sebenarnya dilandasi atas dasar konflik di antara keduanya. Kondisi tersebut telah berdampak pada stagnasi POKJA eduwisata energi terbarukan yang dikembangkan oleh pemuda.

Kedua, pengembangan eduwisata belum ada dampak yang signifikan terhadap pemuda sebagai pengelola, akan tetapi dengan adanya promosi yang dilakukan pemuda telah berdampak pada semakin dikenalnya Pantai Baru Pandansimo yang di dalamnya terdapat eduwisata energi terbarukan. Kondisi ini telah berdampak pada meningkatnya jumlah wisatawan yang berkunjung ke lokasi wisata tersebut, sehingga penghasilan yang diperoleh warga sekitar pun meningkat. Berkaitan dengan hal tersebut, maka meningkatnya penghasilan warga sekitar merupakan penanda terwujudnya ketahanan ekonomi wilayah.

\section{DAFTAR PUSTAKA}

Anonim, 2013. Pengertian Eduwisata (internet). $<$ http://www.upi.edu/spot/id/13> (Diakses pada tanggal 14 Oktober 2015).

Burhan, B. 2003. Analisis Data Penelitian Kualitatif. Jakarta, Raja Grafindo Persada.
Departemen Pertahanan RI. 2008. Buku Putih Pertahanan Indonesia. Jakarta, Departemen Pertahanan Republik Indonesia.

Kusumasari, A. D. 2014. "Peran Karang taruna dalam Usaha Ekonomi Produktif (UEP) Guna Mendukung Ketahanan Ekonomi Keluarga : Studi di Karang Taruna "Widya Taruna”, Desa Kemadang, Kecamatan Tanjungsari, Kabupaten Gunung Kidul, Daerah Istimewa Yogyakarta”. Tesis : Universitas Gadjah Mada.

Lemhannas. 1997. Disiplin Nasional. Jakarta, Balai Pustaka.

Sugiyono. 2007. Memahami Penelitian Kualitatif. Bandung, Alfabeta.

Tarmidi, L. T. 1992. Ekonomi Pembangunan. Pusat Antar Universitas, Studi Ekonomi, Universitas Indonesia.

\section{Peraturan Perundangan}

Undang-Undang Nomor 40 Tahun 2009

Tentang Kepemudaan

\section{Wawancara}

Nukman Riofa’i, Ketua Kelompok Kerja/ POKJA, 19 Februari 2016

Mur dan Arif, pengelola, 29 Februari 2016

Supriyanto, Kepala Desa Poncosari, 03 Maret 2016

Suwandi, ketua POGIAT Dusun Ngentak, 15 April 2016 